\title{
Analysis of Provincial Tourism Sustainable Development Model and Countermeasure
}

\author{
Ren-Xing Zhao ${ }^{{ }^{*}}$, Jian-Qiu Zeng ${ }^{1}$, Jing-Lin Zhao ${ }^{2}$ \\ ${ }^{1}$ School of Economics and Management, Information Economics and Competitiveness Research Center, Beijing University of \\ Posts and Telecommunications, Haidian, Beijing, CHINA \\ ${ }^{2}$ Harbin Institute of Technology, Heilongjiang Association for Science and Technology, Songbei District, Harbin, CHINA
}

Received 16 June 2017 • Revised 8 September 2017 • Accepted 27 September 2017

\begin{abstract}
Tourism has become a pillar industry in developing provincial economy, and the high requirement is put forward on ecological protection, supporting infrastructure, etc. In this paper, China's 31 provinces are studied by establishing a comprehensive evaluation index system, and measured on the basis of 2010-2012 data via TOPSIS statistical model. According the results, the provinces are divided into three types and specific development paths are put forward respectively. Finally, the author provides countermeasures for sustainably developing provincial tourism considering ecology, economy, society, policy and technology.
\end{abstract}

Keywords: provincial tourism, sustainable development, comprehensive evaluation, model

\section{INTRODUCTION}

As the Third Plenary Session of the 18th CPC Central Committee set new goals for China's ecological economy, tourism has become a strategic pillar industry in provincial economic development. As a leisure and service industry, the potentials involve various factors including ecological environment, social environment, economic environment as well as policy and technological environment. Therefore, comprehensive evaluation on provincial tourism's sustainable development potentials is of strategic importance for scientifically arranging provincial tourism resources and realizing the sustainable development.

With annual growth rate of $7 \%$, China's tourism has become one of the fast-developing industries. According to statistics, China's tourism revenue totaled 2.57 trillion yuan in 2012; domestic tourists made 2.957 billion trips; revenue from domestic tourism reached 2.22 trillion yuan; inbound tourists conducted 132 million trips including 57.72 million overnight ones; foreign exchange earnings from tourism were assessed at 50,028 billion yuan; and outbound tourists made 83.18 million trips. The improving tourism industry has sparked economic development and become an important part of economic development strategies. To date, 28 out of the 31 provinces has considered tourism as their key industry for economic growth.

However, tourism has also imposed negative impact to the regions, including environmental pollutions, ecological damages and cultural conflicts in line with the expanding tourism industry; as well as water pollutions, air pollutions, constructive disruptions and overloaded tourism carrying capacity brought about by resource exploitation or massive influxes of tourists (Lindahl et al.,2016). The problems have threatened its reputation as smokeless industry or clean industry (Tao et al., 2004; Hongjian, 2008).

\section{SYSTEMIC ANALYSIS OF PROVINCIAL TOURISM SUSTAINABLE DEVELOPMENT}

From the perspective of system theory, the sustainable development of provincial tourism requires a combined action of internal and external factors of the sustainable development system. Provincial tourism influent by ecological environment, social development, economy and technology (Wang et al., 2016). As to external environment, the development is subject to macro-policies and technology of the provinces which trigger internal 


\section{Contribution of this paper to the literature}

- $\quad$ These provinces should take brand building as a focal point, work out outstanding tourism products through readjusting integrating tourism resources, and then publicize their brand to the world via media.

- With the establishment of resource coordination mechanism and traffic flow mechanism, cooperation among tourism cities would be strengthened and problems including disorderly, iterative development as well as blind competition are eliminated; correspondingly, the scale, uniqueness and complementarily of tourism products are improved.

- These provinces are suggested to enhance their support to tourism enterprises and establish suitable theme tourism products on the basis of its own advantages including the "Ice-Snow Tour" of Heilongjiang and the "MICE Tour" of Hainan.

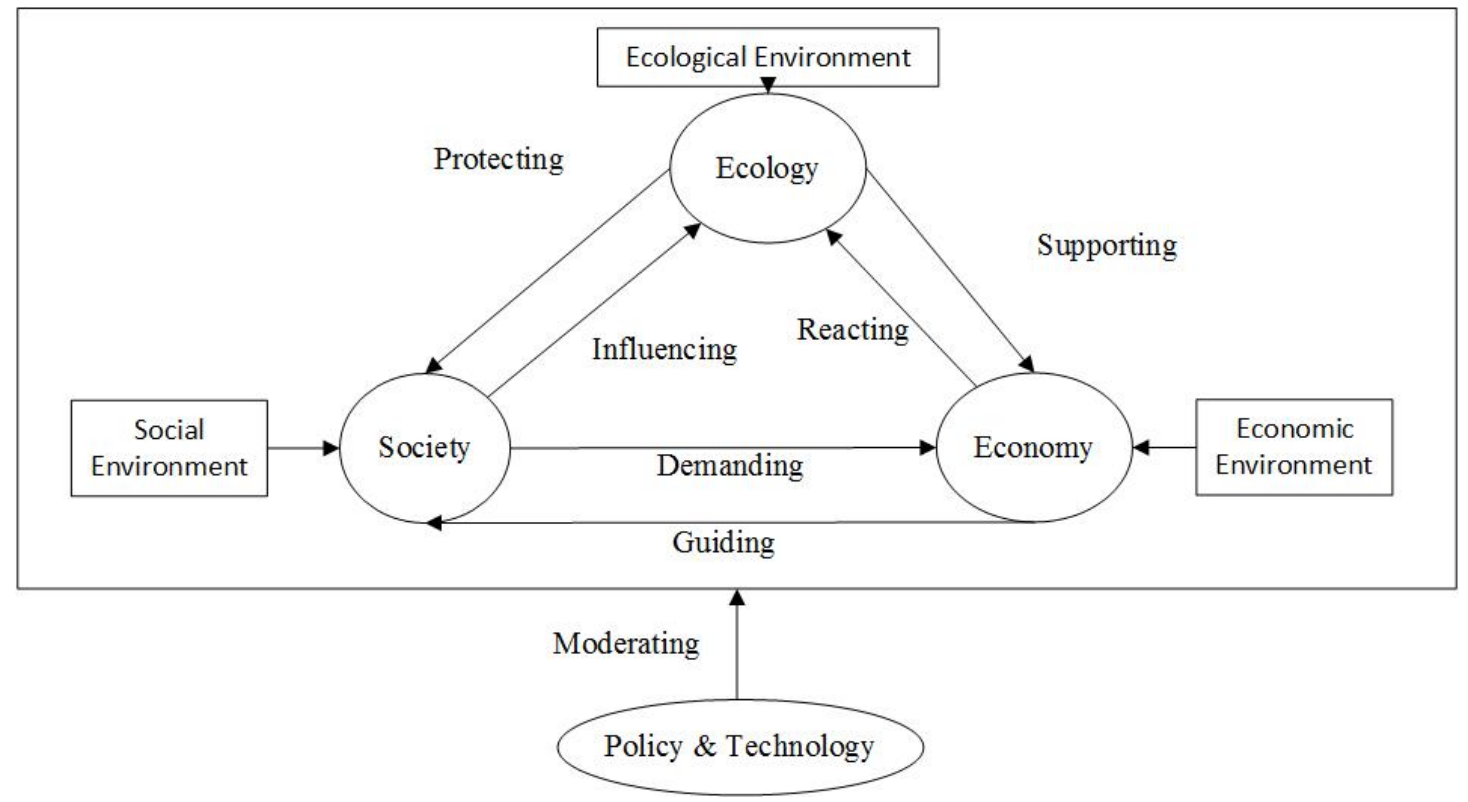

Figure 1. Provincial tourism sustainable development system

operation in line with social, ecological and economic environment. In the internal system, ecology, society and economy interact to maintain the running of the sustainable development. Ecological quality performs as a precondition of rapidly economic growth; in return, economic improvement benefits ecology and drive joint development of a new round (Weiye \& Lingyan, 1995). Interactions among the four subsystems are illustrated in Figure 1.

\section{COMPREHENSIVE ANALYSIS OF PROVINCIAL TOURISM}

As the comprehensive evaluation of provincial tourism sustainable development potentials is a complicated assessment, an index system will be established in this paper in which a statistic model is adopted to assess the potentials of China's 31 provinces.

\section{Index System Construction}

According to the research on provincial tourism sustainable development system, it is obvious that the influential factors include ecological environment, social environment, economic environment as well as policy and technological environment (Liangjian, 2001). In this paper, the evaluation index system has been established corresponding to sustainable development potentials. 
Table 1. Provincial tourism sustainable development evaluation index system

\begin{tabular}{|c|c|}
\hline Influential Factors of Tourism & Evaluation Index \\
\hline \multirow{5}{*}{ Economy } & Per capita GDP \\
\hline & Household consumption level \\
\hline & Annual tourism revenue \\
\hline & Volume of star hotels \\
\hline & Volume of travel agencies \\
\hline \multirow{4}{*}{ Ecology } & Forest coverage rate \\
\hline & Sulfur dioxide emissions \\
\hline & Local fiscal expenditure on environmental protection \\
\hline & Investment on industrial pollution \\
\hline \multirow{5}{*}{ Society } & Passenger turnover volume \\
\hline & Highway density \\
\hline & Rail mileage \\
\hline & Volume of A plus scenic spots \\
\hline & Berths of medical organizations \\
\hline \multirow{3}{*}{ Policy \& Technology } & Volume of patent licensing \\
\hline & Volume of internet users \\
\hline & Satisfaction of tourism policy implementation \\
\hline
\end{tabular}

Table 2. Weighting results of provincial tourism sustainable development index system

\begin{tabular}{cccccccc}
\hline Index & \multicolumn{2}{c}{ Weight } & Index & \multicolumn{2}{c}{ Weight } \\
\hline $\begin{array}{c}\text { Satisfaction of tourism } \\
\text { policy implementation }\end{array}$ & 0.1137 & 0.060782 & 0.087241 & $\begin{array}{c}\text { Household consumption } \\
\text { level }\end{array}$ & 0.0822 & 0.062553 & 0.072377 \\
\hline $\begin{array}{c}\text { Volume of patent } \\
\text { licensing }\end{array}$ & 0.0315 & 0.074415 & 0.052958 & Annual tourism revenue & 0.0944 & 0.082925 & 0.088663 \\
\hline $\begin{array}{c}\text { Volume of internet } \\
\text { users }\end{array}$ & 0.0796 & 0.053326 & 0.066463 & Volume of star hotels & 0.0503 & 0.051316 & 0.050808 \\
\hline $\begin{array}{c}\text { Passenger turnover } \\
\text { volume }\end{array}$ & 0.0359 & 0.052968 & 0.044434 & Volume of travel agencies & 0.1035 & 0.062251 & 0.082876 \\
\hline Highway density & 0.0246 & 0.042159 & 0.03338 & Forest coverage rate & 0.1003 & 0.051809 & 0.076055 \\
\hline $\begin{array}{c}\text { Public service } \\
\text { expenditure }\end{array}$ & 0.0311 & 0.062259 & 0.04668 & $\begin{array}{c}\text { Investment on industrial } \\
\text { pollution }\end{array}$ & 0.0351 & 0.073513 & 0.054307 \\
\hline $\begin{array}{c}\text { Volume of A plus } \\
\text { scenic spots }\end{array}$ & 0.0383 & 0.058654 & 0.048477 & $\begin{array}{c}\text { Local fiscal expenditure on } \\
\text { environmental protection }\end{array}$ & 0.0551 & 0.04262 & 0.04886 \\
\hline $\begin{array}{c}\text { Berths of medical } \\
\text { organizations }\end{array}$ & 0.0134 & 0.059389 & 0.036395 & Sulfur dioxide emissions & 0.0707 & 0.037297 & 0.053999 \\
\hline Per capita GDP & 0.0404 & 0.071764 & 0.056082 & & & & \\
\hline
\end{tabular}

\section{Weighting of Index System}

As index weighting is demonstrated through the relative importance among hierarchies and among indexes within each hierarchy, the scientific, rational and objective setting of weight is directly relevant to the reliability and validity of evaluation results. Since two major methods of weighting, subjectively and objectively, both have merits and demerits (Zhiwei, 2001), the comprehensive evaluation of AHP-entropy is adopted in this study.

(1) AHP weighting method

Based on the AHP processes, provincial tourism development index system is weighted with the adoption of YAHPP software. Results are demonstrated in Table 2.

(2) Entropy method

Follow the Entropy calculation, results are demonstrated in Table 2.

(3) Comprehensive Weighting 
Table 3. Final scores of provincial tourism's sustainability

\begin{tabular}{|c|c|c|c|c|c|}
\hline Province & $\begin{array}{c}\text { General } \\
\text { sustainability }\end{array}$ & $\begin{array}{c}\text { Policy and technological } \\
\text { sustainability }\end{array}$ & $\begin{array}{c}\text { Ecological } \\
\text { sustainability }\end{array}$ & $\begin{array}{c}\text { Social } \\
\text { sustainability } \\
\end{array}$ & $\begin{array}{c}\text { Economic } \\
\text { sustainability }\end{array}$ \\
\hline Guangdong & 0.76 & 0.81 & 1.08 & 0.72 & 0.61 \\
\hline Jiangsu & 0.74 & 0.79 & 1.15 & 0.77 & 0.41 \\
\hline Shandong & 0.72 & 0.62 & 1.24 & 0.67 & 0.59 \\
\hline Zhejiang & 0.66 & 0.67 & 0.81 & 0.72 & 0.48 \\
\hline Henan & 0.51 & 0.48 & 1.02 & 0.41 & 0.39 \\
\hline Liaoning & 0.50 & 0.47 & 0.66 & 0.52 & 0.40 \\
\hline Beijing & 0.49 & 0.50 & 0.52 & 0.64 & 0.24 \\
\hline Hebei & 0.47 & 0.51 & 0.78 & 0.35 & 0.43 \\
\hline Sichuan & 0.46 & 0.49 & 0.77 & 0.35 & 0.41 \\
\hline Shanghai & 0.46 & 0.52 & 0.46 & 0.63 & 0.15 \\
\hline Hunan & 0.45 & 0.47 & 0.79 & 0.34 & 0.42 \\
\hline Hubei & 0.45 & 0.47 & 0.74 & 0.39 & 0.36 \\
\hline Anhui & 0.42 & 0.46 & 0.84 & 0.34 & 0.28 \\
\hline Fujian & 0.42 & 0.49 & 0.40 & 0.38 & 0.44 \\
\hline Shaanxi & 0.39 & 0.43 & 0.51 & 0.29 & 0.45 \\
\hline Inner Mongolia & 0.38 & 0.41 & 0.39 & 0.33 & 0.43 \\
\hline Yunnan & 0.38 & 0.41 & 0.47 & 0.29 & 0.42 \\
\hline Shanxi & 0.38 & 0.46 & 0.41 & 0.30 & 0.40 \\
\hline Jiangxi & 0.37 & 0.42 & 0.49 & 0.28 & 0.40 \\
\hline Guangxi & 0.36 & 0.40 & 0.50 & 0.25 & 0.40 \\
\hline Chongqing & 0.35 & 0.43 & 0.47 & 0.26 & 0.34 \\
\hline Heilongjiang & 0.35 & 0.41 & 0.44 & 0.27 & 0.36 \\
\hline Tianjin & 0.33 & 0.42 & 0.31 & 0.40 & 0.14 \\
\hline Jilin & 0.32 & 0.40 & 0.37 & 0.26 & 0.33 \\
\hline Guizhou & 0.32 & 0.40 & 0.43 & 0.21 & 0.36 \\
\hline Xinjiang & 0.27 & 0.38 & 0.41 & 0.22 & 0.18 \\
\hline Gansu & 0.27 & 0.39 & 0.35 & 0.18 & 0.23 \\
\hline Hainan & 0.24 & 0.35 & 0.18 & 0.18 & 0.27 \\
\hline Ningxia & 0.18 & 0.35 & 0.12 & 0.14 & 0.14 \\
\hline Qinghai & 0.17 & 0.38 & 0.09 & 0.14 & 0.08 \\
\hline Xizang & 0.15 & 0.37 & 0.07 & 0.09 & 0.07 \\
\hline
\end{tabular}

Suppose that $\omega_{k}$ is the weight of index $\mathrm{k}$ generated from the combination of two weighting method mentioned above, and is demonstrated as a liner combination of subjective weight $\mu_{k}$ and objective weight $\rho_{k}(\mathrm{k}=1,2 \ldots \mathrm{m})$. Then,

$$
\omega_{k}=\alpha \mu_{k}+(1-\alpha) \rho_{k}
$$

Based on least square method, the best result is that subjective weight and objective weight account for $50 \%$ respectively, or $a=0.5$, considering the minimum quadratic sum of combination weight-subjective weight and combination weight-objective weight.

\section{Comprehensive Evaluation}

It is drawn from researches at home and abroad that existing evaluation models include tourism ecological footprint, environmental capacity, DPSIR model, ecological capacity of tourism, SG-MA-ISPA model, etc. After comparing advantages and disadvantages of these methods with the consideration of the complication in sustainably developing provincial tourism, the author adopts TOPSIS model to assess comprehensiveness and coordination of the sustainable development.

\section{Cluster Analysis of Provincial Tourism Sustainable Development}

The essential of cluster analysis is to establish a classification method by which sample data are automatically sorted on the basis of their essential closeness when lacking prior knowledge. In the process of clustering provincial tourism sustainability, SPSS19.0 software is adopted in this research to deal with the average value of 2010-2012 statistics. Results are demonstrated as follows: 


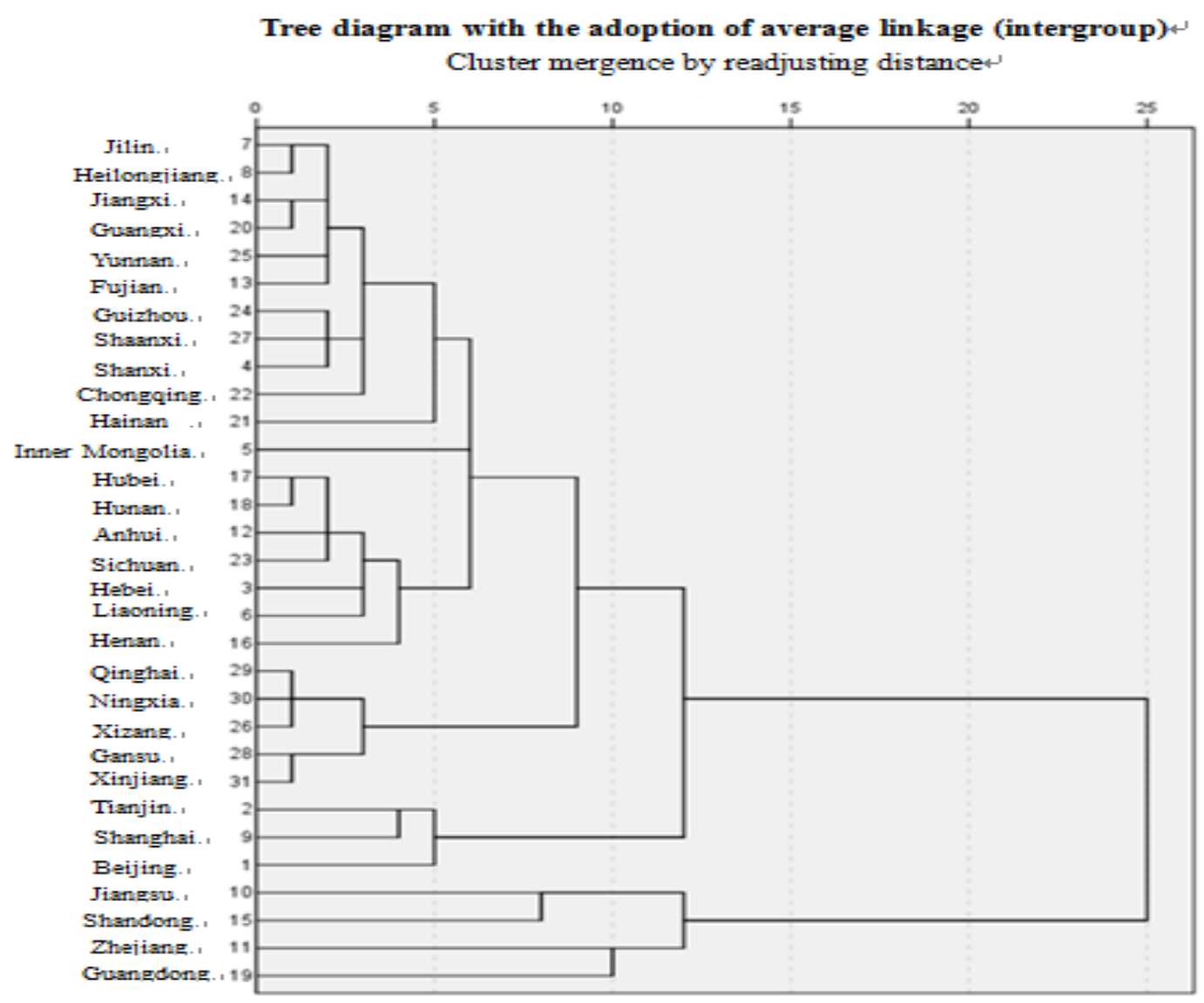

Figure 2. Tree structure of cluster analysis

From the tree structure of cluster analysis, the sustainable development of provincial tourism could be categorized into three types: those with strong sustainability including Guangdong, Zhejiang, Shandong and Jiangsu; those with moderate sustainability including Shanghai, Beijing and Tianjin; and those with weak sustainability covering 24 other provinces like Heilongjiang and Xizang.

\section{PROVINCIAL TOURISM SUSTAINABLE DEVELOPMENT PATH AND SUGGESTIONS}

\section{Provincial Tourism Sustainable Development Path}

It has been demonstrated through comprehensive evaluation and cluster analysis that sustainable development of China's provincial tourism requires improvement. The development mode should be designed specifically in line with different tourism features of each province when carrying out sustainable development planning (Min, 2012).

(1) Brand development mode. The brand development mode is appropriate for Beijing, Shanghai and Tianjin where tourism has reached certain extent as well as economy and society see rapid improvement. Specifically, these provinces should take brand building as a focal point, work out outstanding tourism products through readjusting integrating tourism resources, and then publicize their brand to the world via media.

(2) Regional structure optimization mode. The mode of regional structure optimization is presented for Guangdong, Shandong, Jiangsu and Zhejiang which own many tourist attractions. With the establishment of resource coordination mechanism and traffic flow mechanism, cooperation among tourism cities would be strengthened and problems including disorderly, iterative development as well as blind competition are eliminated; correspondingly, the scale, uniqueness and complementarity of tourism products are improved. Meanwhile, the tourism promotion scheme is set within the region so as to establish brand image and improve the overall competitiveness. 


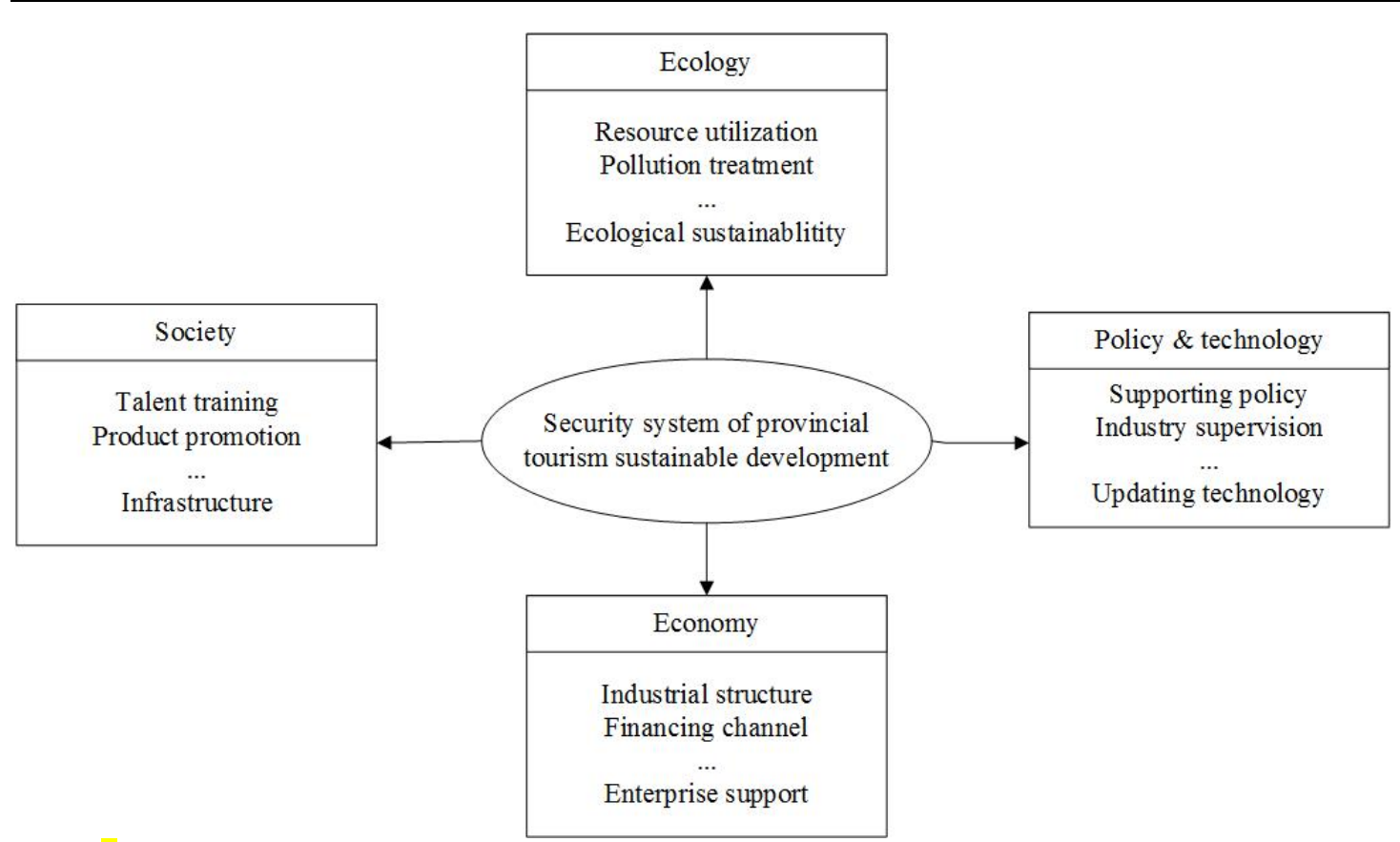

Figure 3. Security system of provincial tourism sustainable development

(3) Theme tourism building and improvement mode. Apart from the seven provinces discussed above, these provinces are suggested to enhance their support to tourism enterprises and establish suitable theme tourism products on the basis of its own advantages including the "Ice-Snow Tour" of Heilongjiang and the "MICE Tour" of Hainan. With the forming of agglomeration effect, sustainable development of these provinces' tourism would be improved rapidly.

\section{Suggestions on Provincial Tourism Sustainable Development}

To realize the sustainable development of tourism, the provinces are advised to work out schemes based on specific conditions. In this paper, a security system of provincial tourism sustainable development is designed and illustrated in Figure 3 (Bin, 2014; Guangrui, 2011).

(1) Ecological environment. As the protection of ecological environment is highly correlated with tourism, the appropriate handing of their relationship is crucial for sustainable development of tourism as well as economy. Therefore, the protection of tourism resource and ecological environment deserves great priority in realizing the industry's sustainable development. Suggested measures include strengthening coordination among industries, optimizing resource allocation and removing disordered exploration.

(2) Economic environment. Since economy serves as a significant support of tourism sustainable development, the provinces are suggested to adjust industrial structure. First, market structure should be optimized to promote the diversification in tourism market. Second, industrial structure requires rationalization to better economic performance of tourism. Meanwhile, financing channels should be broadened and market mechanism ought to be introduced so that sufficient funds and advanced marketing concepts are provided for tourism development.

(3) Social environment. In the aspect of social environment, there exist two focal points: the building of talent teams and the completion of infrastructures. As to the building of talent teams, production, teaching and scientific research should be combined closely to enhance the professional competence of tourism workers. As to the completion of infrastructures, quality and safety of transportation, catering, accommodation and tourism facilities should be strictly monitored. The third party supervising system is suggested to set up for reinforcing evaluation mechanism.

(4) Policy and technological environment. Macro policy is considered as the "baton" for provincial tourism development. With the development of society and economy, decision makers pay increasing attention to the sustainable development of tourism. Therefore, when formulating tourism related policy, the idea of sustainable development is suggested to instill in the laws and regulations. In terms of technology, research institutes are supposed to heighten and popularize the technological content of tourism products; meanwhile, negative effect on local ecology are suggested to be minimized through adopting advanced technology for environment protection and renovation. 


\section{REFERENCES}

Bin, D. (2014). A Discussion of China's Tourism Development in 13th Five Year Plan. Tourism Tribune, 10, 3-5.

Guangrui, Z. (2011). A Rational Thinking of China's Tourism Development. China Soft Science, 02, 16-33.

Gunnar, L. M., \& Folkesson, A.-M. (2016). Attitudes and Language Use in Group Discussions on Socio-Scientific Issues. EURASIA Journal of Mathematics, Science E Technology Education, 12(2).

Hongjian, W., Zhongguang, L., Yanjun, X., \& Juan, W. (2008). Status, Theoretical Foundations and Evaluation System of Researches on Leading Tourism Provinces. Tourism Tribune, 04, 53-57.

Liangjian, W. (2001). A Study of Evaluation Index System and Method for Tourism Sustainable Development. Tourism Tribune, 01, 65-67.

Min, Z., Hong, M., \& Huihui, F. (2012). Research on the Models of Low-carbon Tourism Development Based on the Sustainable Development Theory. Tourism Research, 01, 26-30.

Tao, X., Qiuju, Z., Lianrong, Z. (2004). An Overview of China Tourism Sustainable Development Researches. Journal of Arid Land Resources \& Environment, 06, 123-127.

Wang, Y.-P. (2016). A Study on Kinmen Resident's Perception of Tourism Development and Culture Heritage Impact. EURASIA Journal of Mathematics, Science \& Technology Education, 12(12).

Weiye, M., \& Lingyan, C. (1995). Theory of mechanism. Studies in Science of Science, 04, 2-6+83.

Zhiwei, W. (2001). A Study of State-owned Forest Economic Transition in Northeast China.

\section{http://www.ejmste.com}

